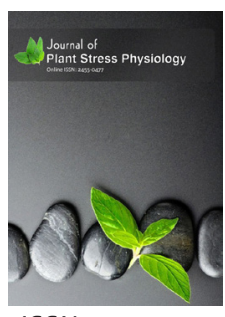

ISSN: $2455-0477$

\title{
Growth, productivity and nutritional
} status of Salicornia brachiata Roxb. cultivated in saline soils supplemented with organic manures under sea water irrigation

\author{
Arumugam Ramasubramanian*, Kavitha Uyyavanthan \\ PG \& Research Department of Botany, Alagappa Government Arts College, Karaikudi - 3, Tamilnadu, India
}

\begin{abstract}
Halophytic crops are being explored for their nutritional, culinary, oilseed, forage/ feed crop, medicinal, and wastewater treatment potential. Along the Palk Bay region, a short term field experiment was conducted at coastal inlands of Kattumavadi village of Puthukottai district, Tamilnadu during the monsoon season of 2017 to evaluate the cultivation potential of Salicornia brachiata Roxb. in coastal sandy loam soil supplemented with different rates of farmyard manure (FYM) and halophytic compost (HC) irrigated with sea water. Observations recorded in the present study clearly indicated that the supplemental fertilizers can play a vital role in restoration of soil fertility, particularly in terms of available nitrogen and organic carbon in saline soils. HC treated plants showed increased biomass production $\left(3240 \mathrm{Kg} \mathrm{ha}^{-1}\right.$ ) at 60 DAP compared to control and other treatments. The application of FYM @ 2 ton ha ${ }^{-1}$ and HC @ 1 ton ha-1 significantly enhanced dry matter production and the proximate analysis exhibited less variation in total phenols and ascorbic acid with the increase in the rates of manure applications.
\end{abstract}

\section{Arumugam}

*Corresponding Author:

Ramasubramanian,

E-mail:drmugam@yahoo.

co.in

KEYWORDS: Salicornia brachiata, halophytic compost, farmyard manure, biomass, sea water irrigation

\section{INTRODUCTION}

World's food production will need to increase by up to $70 \%$ by 2050 as the world's population will reach 9.1 billion, 34 percent higher than today. The developing countries are in urge of developing new management practices to increase the productivity per unit land. Bio-saline agriculture is one of the recent, cost effective options for farming where land and water is not suitable for the conventional agriculture. The benefits of developing saline agriculture enable food, fodder, and biofuel production from degraded lands using low quality water resources (Panta et al., 2014). Saline agriculture might become a viable strategy of future farming to deal with the growing food and biofuel demands of an increasing global population (Mala et al., 2010). Halophytes are potential cash crops in saline agriculture, where they may be used for food, fibre and industrial purposes. Many halophytes have been evaluated for their potential use as crop plants (Flowers et al., 2010), for the re-vegetation and remediation of salt and industrially polluted areas, as floricultural crops (Cassaniti et al., 2013) and as biofilters for aquaculture effluents (Buhmann et al.,
2015). Recently, interest in certain 'functional foods,' which are endowed with exceptional nutritive values, is increasing (Giudice et al., 2010). The new potential halophyte crops, cultivated as cash crops using saline water, meet those special nutritional demands.

Salicornia has been listed as one of the most salt-tolerant species among 1560 halophytes and has been shown to maintain normal growth even when soil $\mathrm{NaCl}$ concentration exceeds $1.3 \mathrm{M}$, two times greater than full-strength seawater salinity (Ventura et al., 2011). Some studies indicate that Salicornia inhabits the broadest range of salinity and has very little phenotypic response to salinity gradient (Singh et al., 2018). However, skepticism about their feasibility for use as alternative crop or forage species still remains. Since earlier biosaline agriculture trials experienced indirect influences of soil parameters such as $\mathrm{pH}$ and elemental deficiency, the growing protocols need to be adapted to the existing cultivation conditions, taking not only salt tolerance into account (Ventura et al., 2013). Several organic materials have been researched in the aspect of improving soil physical properties (Lordan et al., 2013), but, limited literature

Copyright: $\odot$ The authors. This article is open access and licensed under the terms of the Creative Commons Attribution License (http://creativecommons.org/licenses/by/4.0/) which permits unrestricted, use, distribution and reproduction in any medium, or format for any purpose, even commercially provided the work is properly cited. Attribution - You must give appropriate credit, provide a link to the license, and indicate if changes were made. 
is available on the combination of organic manure and sea water irrigation for crop productivity in the soils of coastal inlands. The objective of this study was to determine the cropping potential of Salicornia brachiata Roxb., a halophytic leafy vegetable in the coastal inlands subjected to manure supplementation and sea water irrigation. No study in the literature was found on the salinity-fertility interaction of the halophytic species, so this study was initiated in order to facilitate and formulate a feasible reclamation process for the saline barren land along the coast of Palk Bay region.

\section{MATERIAL AND METHODS}

\section{Experimental Design}

The coastal village Kattumovadi (Lat. 10²'N; Long. 79¹2'E) of Puthukottai district along the Indian Palk Bay region has been selected for the current field studies. The potentiality of the site was identified based on the tidal wave patterns, mudflats with desirable tidal inundation patterns, accessibility, vegetation, tidal coverage, coarse fractions and debris, area available for planting etc. The field experiment was conducted at the barren coastal inland near seashore $(\leq 1000 \mathrm{~m})$ in randomized complete block design with three replicates, where sea water salinity distributed in the main plots, while farmyard manure (FYM) and halophytic compost (HC) treatments were randomly arranged in the sub-plots. The soil of experimental field was sandy loam in texture with low available N, P and K. The treatments used in this experiment were: T0: Control (no manure);T1:HC@0.5 ton ha' ${ }^{-1}$ T2:HC@1 ton ha' ${ }^{-1}$; T3: HC @2ton ha-1,T4:FYM@1ton ha' ${ }^{-1}$; 5:FYM@2ton ha ${ }^{-1}$ and T6: FYM@5 ton ha ${ }^{-1}$. For each treatment, three replicates of $6 \mathrm{x} 4 \mathrm{ft}$ size plots were earmarked with raised bunds all around to minimize the movement of water where each plot consists of 5 rows at uniform distance in between them.

Farmyard manure (FYM) was collected from the local dairy farm, air dried under the shade and large pieces were crushed. Halophytic compost (HC) used in this experiment was prepared using vegetative parts of Clerodendron inerme L., Ipomoea pescaprae (L.), rice straw, animal wastes with a fungal decomposer Pleurotus sajor-caju (Fr.) Singer (Kalaiarasi \& Arumugam, 2014). Both HC and FYM were added in single dose by incorporating into the soil to a depth of $10-30 \mathrm{~cm}$, two weeks before planting. The healthy uniform $(8-10 \mathrm{~cm})$ seedlings of Salicornia brachiata Roxb. were collected from their natural field condition along the Palk Bay coastal zone and replanted in the experimental plots in rows where plant to plant distance was maintained at $15-20 \mathrm{~cm}$. The plots were irrigated with seawater and the required amount of water was determined based on the soil moisture content of each treatment. The physico-chemical characters of halophytic compost, farmyard manure, experimental field soil and seawater used for irrigation were given in the Table 1 .

\section{Growth Attributes}

Plant growth was measured at 30 and 60 DAP in terms of plant height, number of leafy shoots per plant, number of branches, biomass, percent tissue water content (TWC\%) and succulence index (Ls) (Slama et al., 2008).

\section{Proximate Compounds}

Fully expanded leafy shoots were harvested and used for the biochemical analysis as per standard methods. Chlorophyll content was determined as described by Arnon (1949). Protein (Lowry et al., 1951) and proline (Bates et al., 1973) were also estimated as per standard procedures. Total ash content was estimated by furnaces incineration gravimetric method described by James (1995) and AOAC (1990). The membrane stability index (MSI) was determined as described by Premchandra et al. (1990) by measuring the electrical conductivity.

\section{Total Phenol Content}

Total phenolic contents were determined by the Folin Ciocalteu method proposed by Lin and Tang (Lin \& Tang, 2007) $0.1 \mathrm{~mL}$ of the supernatant it was mixed with $2.8 \mathrm{~mL}$ of deionized water, $2.0 \mathrm{~mL}$ of $2 \%$ sodium carbonate $\left(\mathrm{Na}_{2} \mathrm{CO}_{3}\right)$, and $0.1 \mathrm{~mL}$ of FolinCiocalteau reagents. After incubation at room temperature for $30 \mathrm{~min}$, the absorbance of the reaction mixture was measured at $750 \mathrm{~nm}$ on a UV-visible spectrophotometer. The total phenol content was expressed as milligram gallic acid equivalents (GAE) $100 \mathrm{~g}^{-1}$ fresh weight.

\section{Ascorbic Acid}

Leafy shoots of $S$. brachiata was extracted with oxalic acid at $0.4 \%$ in a ratio of $1: 10 \mathrm{w} / \mathrm{v}$ and put in a dark room for 20 min before its centrifugation at $660 \mathrm{rpm}$. Later, $1 \mathrm{~mL}$ of the supernatant was mixed with sodium acetate buffer solution and a 2, 6-dichlorophenol indophenol solution. The absorbance of the solution was measured at $520 \mathrm{~nm}$ and the ascorbic acid content was calculated on the basis of an adjusted calibration curve of L-ascorbic acid standard, reported as ascorbic acid mg $100 \mathrm{~g}-1$ fresh weight (Durust et al., 1997).

\section{Nutrient Status and Food Value}

The available sodium and potassium was estimated using the flame photometer method (Stanford \& English, 1949). The available chloride content was estimated with the Mohr's titration method (Jackson, 1967) and other mineral nutrients were determined by Inductively Coupled Plasma Atomic Absorption Spectrometry (Optima 2000DV, PerkinElmer, USA). Carbohydrate, crude fibre was determined by the method of James (1995), crude fat was determined by solvent extraction gravimetric method described by Kirk and Sawyer (1980). The nutritional value of Salicornia was calculated as per the formula used by Nile and Khobragade (2009).

\section{RESULTS AND DISCUSSION}

\section{Environmental Factors}

Cultivating halophytes irrigated with saline water, has long and recurrently been considered an alternative farming method 
Table 1: Physicochemical parameters of the experimental soil (ES), farmyard manure (FYM), halophytic compost (HC) and sea water (SW - $\left.\mathrm{mg} \mathrm{L}^{-1}\right)$

\begin{tabular}{|c|c|c|c|c|}
\hline Parameters & SW & ES & $\mathrm{HC}$ & FYM \\
\hline $\mathrm{pH}$ & $7.83 \pm 0.04$ & $8.12 \pm 0.09$ & $7.97 \pm 0.13$ & $7.21 \pm 0.11$ \\
\hline Temperature ${ }^{\circ} \mathrm{C}$ & $30.6 \pm 0.31$ & $36.4 \pm 0.28$ & $33.6 \pm 0.18$ & $34.6 \pm 0.27$ \\
\hline $\mathrm{EC}\left(\mathrm{dS} \mathrm{m}^{-1}\right)$ & $46.8 \pm 0.37$ & $11.52 \pm 0.23$ & $8.08 \pm 0.09$ & $1.69 \pm 0.13$ \\
\hline OM \% & $0.73 \pm 0.03$ & $2.06 \pm 0.04$ & $42.87 \pm 0.11$ & $19.4 \pm 0.21$ \\
\hline $0 \mathrm{C} \%$ & $0.32 \pm 0.01$ & $1.34 \pm 0.05$ & $31.67 \pm 0.19$ & $14.8 \pm 0.12$ \\
\hline$N\left(m g ~ g^{-1}\right)$ & $0.451 \pm 0.01$ & $1.06 \pm 0.02$ & $2.44 \pm 0.04$ & $2.09 \pm 0.09$ \\
\hline$P\left(m g g^{-1}\right)$ & $0.208 \pm 0.03$ & $0.221 \pm 0.01$ & $0.334 \pm 0.03$ & $0.312 \pm 0.03$ \\
\hline $\mathrm{K}\left(\mathrm{mg} \mathrm{g}^{-1}\right)$ & $0.389 \pm 0.01$ & $0.375 \pm 0.02$ & $0.746 \pm 0.07$ & $0.546 \pm 0.04$ \\
\hline $\mathrm{Na}\left(\mathrm{mg} \mathrm{g}^{-1}\right)$ & $20.33 \pm 0.28$ & $18.91 \pm 0.20$ & $6.43 \pm 0.13$ & $1.83 \pm 0.10$ \\
\hline $\mathrm{Ca}\left(\mathrm{mg} \mathrm{g}^{-1}\right)$ & $0.423 \pm 0.04$ & $0.575 \pm 0.01$ & $0.695 \pm 0.03$ & $0.672 \pm 0.05$ \\
\hline $\operatorname{Mg}\left(\mathrm{mg} \mathrm{g}^{-1}\right)$ & $0.508 \pm 0.02$ & $0.578 \pm 0.01$ & $0.678 \pm 0.06$ & $0.702 \pm 0.04$ \\
\hline $\mathrm{Cl}\left(\mathrm{mg} \mathrm{g}^{-1}\right)$ & $22.12 \pm 0.27$ & $20.64 \pm 0.38$ & $8.23 \pm 0.12$ & $2.04 \pm 0.08$ \\
\hline Fe (ppm) & $0.056 \pm 0.01$ & $0.067 \pm 0.01$ & $0.126 \pm 0.03$ & $0.131 \pm 0.02$ \\
\hline Zn (ppm) & $0.018 \pm 0.01$ & $0.024 \pm 0.01$ & $0.091 \pm 0.03$ & $0.089 \pm 0.01$ \\
\hline Cu (ppm) & $0.027 \pm 0.01$ & $0.041 \pm 0.01$ & $0.037 \pm 0.03$ & $0.044 \pm 0.02$ \\
\hline
\end{tabular}

Values are mean $\pm \mathrm{SE}$

that does not need freshwater and makes use of marginal land like coastal desert areas (Ventura et al., 2015) Plant response to salinity varies appreciably with many environmental factors (e.g., soil fertility, soil physical conditions, irrigation methods and climate) and plant factors (e.g., growth stages, variety and rootstock). The environmental factors prevailed in the area during the study period 2017 - 2018 was given in Fig 1. Mean daily irradiance along the duration of the experiment was 280 $\pm 66 \mu \mathrm{mol}$ PAR $\mathrm{m}^{-2} \mathrm{~s}^{-1}$. Mean air temperature for the same period was $35.0 \pm 1.2^{\circ} \mathrm{C}$, while daily minimum mean was 25.0 $\pm 1.0^{\circ} \mathrm{C}$, and the daily maximum air temperature $36.5 \pm 2.0^{\circ} \mathrm{C}$. Mean daily water temperature for the experimental period was $31.6 \pm 1.5^{\circ} \mathrm{C}$, while daily minimum was $20.8 \pm 1.8^{\circ} \mathrm{C}$. During the period, a maximum rainfall of $129 \mathrm{~mm}$ was observed in September and a minimum of $2 \mathrm{~mm}$ in April.

\section{Growth Parameters}

During the experimental period (60 days), nearly 10\% mortality was observed in control plots whereas no mortality was observed in any manure treated plots. This is consistent with the study of Kumar et al. (2012) who stated that the survival capacity values of plants were significantly improved by organic manure addition. The results on the effect of FYM and HC on the growth parameters of $S$. brachiata are presented in Table 2. S. brachiata has attained a maximum height of $26.7 \mathrm{~cm}$ on 60 DAP under sea water irrigation with the supplementation of HC@1 ton ha'-1.

In general, plant height increased with increasing level of $\mathrm{HC}$ up to 1 ton ha-1 (T2) and FYM up to 2 ton ha-1 (T5), beyond this no more significant increases. According to Martinez-Garcia (2010), the decreased growth of S. brachiata in control plots were due to drying soil at which they could no longer extract water from the soil. Maximum shoot and root length were observed in T2 $(16.3 \mathrm{~cm} \& 10.3 \mathrm{~cm})$ followed by T3 $(15.7 \mathrm{~cm}$ $\& 9.43 \mathrm{~cm})$ and $\mathrm{T} 5(15.3 \mathrm{~cm}$ and $9.21 \mathrm{~cm})$. Maximum lateral branches was observed in T2 (11.9) than T0 (6.8). However, throughout the experiment, the number of nodes and side branches on the main stem did not significantly differ among the

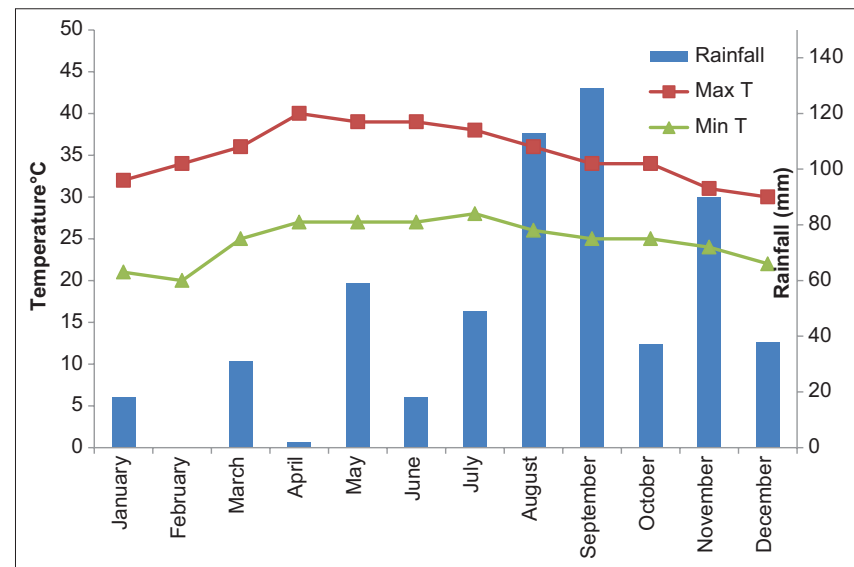

Figure 1: Metereological data prevailed in the study area during 2017

organic manure treatments. Arya (2017) found that phosphorus application with FYM showed a maximum height increment of $35.9 \%$ in Salvadora persica, a perennial halophyte under field condition compared to control. Noaman (2004) observed that the differences between fertilizer treatments for different halophyte species regarding plant height were not significant at the initial stage of growth and thereafter the differences became apparent at the third stage (60 DAP). Higher shoot/ root ratio in the current study indicated that this halophyte accumulate greater rootstocks with age, which enabled them to withstand high soil salinity levels (Mala et al., 2010). The linear regression analysis indicated significant positive correlation between $\mathrm{S}$ : R and biomass productivity $\left(\mathrm{r}^{2}=0.840\right)$ (Fig 2.). Similar results were reported in different glycophytes as well as halophytes under saline conditions. In a previous study, Bai et al. (2017) reported that one-time application of dairy manure rapidly increased soil organic matter in mudflat saline soil, which provided good conditions for growth of ryegrass. Sheikhi and Ronaghi (Sheikhi, \& Ronaghi, 2013) observed that the application of vermicompost increased plant growth by mitigating the negative effects of high concentrations of $\mathrm{Na}$ and $\mathrm{Cl}$ in saline soils. Tawfik et al. (2019) found that the addition of chicken manure to the soil has been shown to significantly 
increase the growth characteristics of Atriplex which may be related to the important role of nitrogen, phosphorus and potassium in plant tissues which reflects its vegetative growth. The tissue water content (TWC \%) in control plants was higher $(73.2 \%)$ than the manure treated plants and there was also no significant difference between the treatments. The soil as well as sea water salinity caused a progressive increment in tissue water content, thereby increased the turgor in the leafy shoots of control plants. The capacity of S. brachiata, to maintain high TWC in their leaves, despite of high external salinity might have a protective role from the deleterious effects of salinity (Parida et al., 2016). Salicornia brachiata supplemented with halophytic compost (l ton $\mathrm{ha}^{-1}$ ) has attained a maximum above ground biomass (38.8 g/plant) when compared to control (23.8 g/plant). The plants supplied with HC @ 1 ton ha-1 showed increase in specific growth rate (SGR) $\left(4.36 \mathrm{~g} \mathrm{~m}^{-2} \mathrm{~d}^{-1}\right)$ followed by FYM@2 ton ha-1 $\left(3.59 \mathrm{~g} \mathrm{~m}^{-2} \mathrm{~d}^{-1}\right)$ as compared to control (Table 3) with a maximum productivity of $0.324 \mathrm{Kg} \mathrm{m}^{-2}$. Non- significant differences were noted in the values of MSI

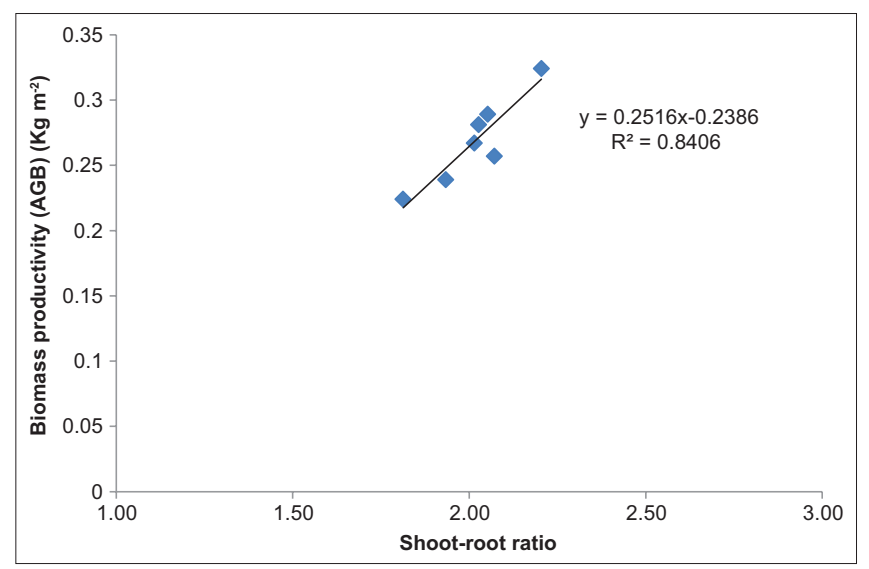

Figure 2: Correlation between Shoot - root ratio and Biomass productivity (AGB) of Salicornia under sea water irrigation and Ls among fertilizer treatments under salinity condition. However, HC and FYM applications significantly decreased MSI, with the optimal effect $(36.6 \%$ ) being noted in the FYM ( 5 ton ha ${ }^{-1}$ ) treatment. Abbasi et al. (2014) demonstrated that moderate exogenous $\mathrm{K}+$ application may effectively diminish the salinity-induced damage to cellular membrane. Adequate $\mathrm{K}+$ supply may reduce the peroxidation of unsaturated fatty acids, and increased content of unsaturated fatty acid helps to improve the membrane fluidity (Zemanová et al., 2015). Our results are supported by Liu et al. (2012) who also observed less membrane damage and enhanced growth in Tamarix chinensis, Suaeda salsa, Salicornia europaea, and Limonium bicolor under low salinity. Similar results were reported with different biofertilizers in various salt tolerant glycophytes, where the stimulatory effect of biofertilizers is proposed to be mainly due to the bacterial release of nitrogen, phosphorus and indole-3-acetic acid in the rhizosphere (Rothballer et al., 2005). Earlier studies revealed that biofertilizer inoculation reduced the deleterious effects of $\mathrm{NaCl}$ on growth, increased the nutritional assimilation of plant (total N, P and K), and also improved soil properties, such as organic matter content and total $\mathrm{N}$ in soil (Hamdia et al., 2004).

\section{Biomass Productivity}

The organic supplementation in the present study at low level showed significant increase in the halophytic biomass productivity of S. brachiata (Table 3). Maximum fresh (28.8g) and dry weight $\left(2.96 \mathrm{~g} \mathrm{~g}^{-1}\right)$ were observed in plants treated with HC (T2) followed by FYM (T5) (2.38 $\left.\mathrm{g} \mathrm{g}^{-1}\right)$ as compared to the control. The increase in fresh weight of the leafy shoots can be attributed to the increase in nodal thickness and the accumulation of ions and water in the tissues (Khan et al., 2009). Soil amendments of HC up to 1 ton $\mathrm{ha}^{-1}$ and FYM up to 2 ton $\mathrm{ha}^{-1}$ exhibited increased above-ground biomass and beyond that biomass production was insignificant. The possible

Table 2: Growth characteristics (60 DAP) of Salicornia brachiata cultivated under sea water irrigation

\begin{tabular}{|c|c|c|c|c|c|}
\hline Treatments & $\mathrm{SL}(\mathrm{cm})$ & $\mathrm{RL}(\mathrm{cm})$ & LB & TWC (\%) & MSI (\%) \\
\hline T0 & $12.2 \pm 0.26^{d}$ & $6.73 \pm 0.14^{\mathrm{e}}$ & $6.8 \pm 0.17^{d}$ & $73.2 \pm 0.08^{a}$ & $46.4 \pm 0.05^{a}$ \\
\hline T1 & $16.8 \pm 0.32^{\mathrm{c}}$ & $8.11 \pm 0.08^{d}$ & $9.3 \pm 0.09^{b c}$ & $67.2 \pm 0.11^{b}$ & $42.6 \pm 0.16^{b}$ \\
\hline T2 & $20.9 \pm 0.43^{a}$ & $9.48 \pm 0.17^{a}$ & $11.9 \pm 0.13^{a}$ & $67.1 \pm 0.17^{b}$ & $40.6 \pm 0.25^{c}$ \\
\hline T3 & $17.9 \pm 0.08^{b}$ & $8.83 \pm 0.12^{b}$ & $10.3 \pm 0.09^{b}$ & $66.2 \pm 0.23^{b}$ & $38.6 \pm 0.11^{d}$ \\
\hline T4 & $15.7 \pm 0.12^{d}$ & $8.12 \pm 0.19^{d}$ & $7.3 \pm 0.12^{d}$ & $65.4 \pm 0.13^{c}$ & $40.4 \pm 0.06^{c}$ \\
\hline T5 & $17.3 \pm 0.17^{\mathrm{b}}$ & $8.43 \pm 0.11^{c}$ & $7.9 \pm 0.09^{c}$ & $65.2 \pm 0.17^{c}$ & $39.1 \pm 0.17^{c}$ \\
\hline T6 & $16.2 \pm 0.14^{c}$ & $8.09 \pm 0.09^{d}$ & $7.1 \pm 0.11^{d}$ & $65.1 \pm 0.09^{c}$ & $36.6 \pm 0.08^{d}$ \\
\hline
\end{tabular}

SL: Shoot length; RL: Root length; LB: No. of Lateral branches; TWC: Tissue water content; MSI: Membrane stability index; Values are Mean \pm SE; Values followed by same letter are not significant at $p>0.05$

Table 3: Above ground biomass (AGB) and productivity (60 DAP) of S. brachiata cultivated under sea water irrigation

\begin{tabular}{lcccc}
\hline Treatments & Fresh weight $(\mathrm{g} /$ plant $)$ & Dry weight $(\mathrm{g} /$ plant $)$ & Specific Growth rate $\left(\mathrm{g} \mathrm{m}^{-2} \mathrm{~d}^{-1}\right)$ & Productivity $\left(\right.$ Kg m $\left.{ }^{-2}\right)$ \\
\hline T0 & $23.8 \pm 0.27^{\mathrm{d}}$ & $8.11 \pm 0.09^{\mathrm{e}}$ & $2.69 \pm 0.07^{\mathrm{d}}$ & $0.224 \pm 0.009^{\mathrm{d}}$ \\
T1 & $29.6 \pm 0.34^{\mathrm{c}}$ & $10.12 \pm 0.07^{\mathrm{c}}$ & $3.34 \pm 0.12^{\mathrm{c}}$ & $0.257 \pm 0.008^{\mathrm{c}}$ \\
T2 & $38.8 \pm 0.38^{\mathrm{a}}$ & $12.36 \pm 0.13^{\mathrm{a}}$ & $4.36 \pm 0.09^{\mathrm{a}}$ & $0.324 \pm 0.006^{\mathrm{a}}$ \\
T3 & $30.9 \pm 0.56^{\mathrm{bc}}$ & $11.18 \pm 0.06^{\mathrm{b}}$ & $3.48 \pm 0.08^{\mathrm{b}}$ & $0.281 \pm 0.003^{\mathrm{b}}$ \\
T4 & $24.6 \pm 0.26^{\mathrm{d}}$ & $9.06 \pm 0.12^{\mathrm{d}}$ & $2.78 \pm 0.06^{\mathrm{d}}$ & $0.239 \pm 0.005^{\mathrm{d}}$ \\
T5 & $31.9 \pm 0.29^{\mathrm{b}}$ & $10.74 \pm 0.08^{\mathrm{bc}}$ & $3.59 \pm 0.11^{\mathrm{b}}$ & $0.289 \pm 0.006^{\mathrm{b}}$ \\
T6 & $28.3 \pm 0.33^{\mathrm{c}}$ & $9.79 \pm 0.05^{\mathrm{d}}$ & $3.19 \pm 0.13^{\mathrm{c}}$ & $0.267 \pm 0.006^{\mathrm{c}}$ \\
\hline
\end{tabular}

Values are Mean \pm SE Values followed by same letter are not significant at $p>0.05$ 
reason could be the higher levels of organic supplementation reduced the soil salinity where $S$. brachiata requires high salinity for optimal growth (Mala et al., 2010). Under high salinity, the major growth limitation encountered by halophytes was attributed to nutrient shortages. Radulovich et al. (2017) conducted a fertilizer-addition trial and found that Avicennia plantlets not receiving fertilizer continued with stagnant growth while those receiving fertilizer rapidly resumed growth and at a larger rate than average. It was observed in the present study that different plant parts were not equally affected by salinity, the growth of shoots in control plants was more suppressed than that of roots. Decrease in root/shoot dry weight ratio of fertilized S. brachiata suggested that fertilizer application has supported shoot growth more than root growth even under highly saline conditions. The dry weight increase could be attributed to the accumulation of inorganic salts and organic matter in the plant tissues.

The maximum halophytic productivity of $0.324 \mathrm{~kg} \mathrm{~m}^{-2}$ was recorded at 60 DAP from $S$. brachiata grown in saline soils amended with HC@1 ton ha ${ }^{-1}$ (T2) compared to the control $\left(0.224 \mathrm{~kg} \mathrm{~m}^{-2}\right)$. This (approx. 9.84 ton ha-1) was much closer to the production of S. bigelovii (11 ton ha-1) at full maturity by Abdal (2009) in sandy soils of coastal areas in Kuwait. The increased biomass production might be due to the application of compost that increases soil organic matter and improves a number of soil properties including water-holding capacity, oxygen content, soil fertility, reduces soil erosion, improves solar heat absorption, increases water infiltration rates, reduces nutrient leaching, which in turn increases crop growth and yields (Hussein et al., 2012). Moreover, the increased halophytic productivity in the saline soils amended with organic manure might be due to the enhanced release of nitrogen from $\mathrm{HC}$ and FYM. Similar to our findings, Pandya et al. (2010) observed an increase of $51 \%$ biomass production in Salicornia with the addition of $100 \mathrm{~kg} \mathrm{~N} \mathrm{ha}^{-1}$ over control. Several studies on the nutritional conditions necessary to faster growth of Salicornia have identified the need for extremely high quantities of nitrogen fertilizer (Rueda-Puente et al., 2004). Hussein et al. (2012) mentioned that the increase in growth characters could be due to that nitrogen sharing in building up and move carbohydrates in plant parts to improve the growth and yield characters. According to Ventura and Sagi (2013), nitrate was the preferred N-source for Salicornia, resulting in 60\% higher yields compared to ammonium fertilized plants. Similarly, the application of molybdenum as a foliar spray during seawater cultivation enhanced yield by accelerating the activities of both nitrate reductase (NR) and xanthine dehydrogenase (XDH) in plants fed either nitrate or ammonium (Ventura et al., 2013). Abusuwar and Al-Solimani (2013) stated that optimal use of NPK fertilizers enhanced crop yield and forage quality by minimizing $\mathrm{Na}+$ toxicity under saline conditions. Balakrishnan et al. (2010) observed increased yield parameters such as fresh and dry weight of pod, length and breadth of pod in Vigna grown under Suaeda compost than other mangrove composts and control. Besides the fertilization in the plants natural habitat, Kudo and Fujiyama (2010) growing Salicornia plants in greenhouses reported an increase in biomass with $\mathrm{N}$ addition. Our results are on par with Webb et al. (2012) who observed an increase in above-ground growth of S. europaea irrigated daily for a short period, with an increase in $\mathrm{N}$ concentration up to $4 \mathrm{mmol} \mathrm{NH}^{+} \mathrm{l}^{-1}\left(0,2,4 \mathrm{mmol} \mathrm{l}^{-1}\right)$, and no further increase at $6 \mathrm{mmol} \mathrm{l}^{-1}$.

\section{Photosynthetic Pigments}

Chlorophyll is the basis of photosynthesis and its content is a key indicator for plant growth under saline conditions. Salinity admittedly hinders numerous morphophysiological attributes like plant photosynthetic capacity by reducing Chls contents (Abbasi et al.,2014). Under saline condition, the contents of Chl were enhanced by all the level of organic manure application, while those values decreased sharply at control treatment (Table 4). The decrease of chlorophyll is mainly attributed to the elevated cytosolic $\mathrm{Na}+$ and $\mathrm{Cl}$ - which resulted in both reduce rate of chlorophyll biosynthesis and its faster degradation (Tavakkoli et al.,2011). Similar results had been reported by several workers in a number of halophytes such as Avicennia sp. and Aegiceras corniculatum (Tejada et al., 2006). Chlorophyll content was statistically differ with the application of HC, FYM and the maximum total chlorophyll was observed in S. brachiata at T2 $\left(0.694 \mathrm{mg} \mathrm{g}^{-1}\right)$. The chlorophyll 'a' was always higher than that of chlorophyll 'b' at all levels. Sea water salinity induced significant decreases in chlorophyll contents of S. brachiata in control plots whereas, HC and FYM application effectively alleviated the salinity-induced injuries. These results are in agreement with those obtained by El-Quesni et al. (2013); they reported that chlorophyll a, b and carotenoids were increased in Jatropha seedlings treated with algae, phosphorien, microbien and compost compared to control plants. Tawfik et al. (2019) reported that biofertilizer inoculation generally increased the content of chlorophyll $\mathrm{a}+\mathrm{b}$ as compared with control. Abbasi et al. (2014) reported that potassium application may effectively alleviate the salinity-induced decreases of Chl contents of maize hybrids in field conditions. Islam et al. (2014) observed significant influence of chlorophyll pigments on shoot biomass, as the amount of sequestered carbon is generally proportional to the overall pigment content in the shoot. This statement can be supported by our observation where leaf shoots with high chlorophyll content had high biomass yield in S. brachiata as high chlorophyll content resulted in high photosynthesis rate.

\section{Proximate Analysis}

The protein content of $S$. brachiata was increased with the application of vermicompost and farmyard manure compared to control (Table 5). Under sea water irrigation, the maximum protein observed was $\left(23.2 \mathrm{mg} \mathrm{g}^{-1}\right)$ in plants treated with HC @ 1 ton ha-1 (T2) and lowest content (18.1 $\mathrm{mg} \mathrm{g}^{-1}$ ) was observed in control plants (T0). Similar results were observed under field condition where the protein content increased with increasing $\mathrm{NaCl}$ concentrations in certain halophytes such as Helochola setulosa (Joshi et al., 2002) and Thellanjiella halophila. In general, the protein content insignificantly differed between the organic manure treatments. Similar results were obtained by Meychik et al. (2013) who found that upon a decrease or an increase in $\mathrm{NaCl}$ concentration (from 250 to 0.5 or from 250 
Table 4: Chlorophyll, proline, phenols and ascorbic acid contents in $S$. brachiata cultivated under sea water irrigation

\begin{tabular}{|c|c|c|c|c|c|}
\hline Treatments & $\mathrm{Chl}^{\prime} \mathrm{a}\left(\mathrm{mg} \mathrm{g}^{-1}\right)$ & $\mathrm{Chl}^{\prime} b\left(\mathrm{mg} \mathrm{g}^{-1}\right)$ & Proline $\left(\mu \mathrm{mol} \mathrm{g}^{-1}\right)$ & Phenol (mg $\left.100 \mathrm{~g}^{-1}\right)$ & Ascorbic acid (mg $\left.100 \mathrm{~g}^{-1}\right)$ \\
\hline T0 & $0.377 \pm 0.08^{c}$ & $0.262 \pm 0.12^{c}$ & $42.7 \pm 0.21^{a}$ & $1.93 \pm 0.19^{a}$ & $6.23 \pm 0.31^{a}$ \\
\hline $\mathrm{T} 1$ & $0.368 \pm 0.11^{d}$ & $0.278 \pm 0.11^{c}$ & $36.2 \pm 0.35^{b}$ & $1.62 \pm 0.13^{b}$ & $5.72 \pm 0.12^{b}$ \\
\hline T2 & $0.392 \pm 0.13^{a}$ & $0.302 \pm 0.09^{a}$ & $36.1 \pm 0.23^{b}$ & $1.56 \pm 0.16^{b}$ & $5.56 \pm 0.26^{b}$ \\
\hline T3 & $0.379 \pm 0.05^{c}$ & $0.282 \pm 0.05^{b}$ & $35.7 \pm 0.19^{c}$ & $1.43 \pm 0.11^{c}$ & $4.92 \pm 0.17^{c}$ \\
\hline T4 & $0.365 \pm 0.07^{d}$ & $0.272 \pm 0.11^{c}$ & $36.1 \pm 0.26^{b}$ & $1.53 \pm 0.17^{\mathrm{b}}$ & $5.53 \pm 0.21^{b}$ \\
\hline T5 & $0.387 \pm 0.06^{b}$ & $0.287 \pm 0.07^{b}$ & $35.8 \pm 0.16^{c}$ & $1.41 \pm 0.14^{c}$ & $5.41 \pm 0.34^{b}$ \\
\hline T6 & $0.374 \pm 0.11^{c}$ & $0.284 \pm 0.13^{b}$ & $35.3 \pm 0.14^{c}$ & $1.34 \pm 0.28^{d}$ & $4.94 \pm 0.28^{c}$ \\
\hline
\end{tabular}

Values are Mean $\pm S E$; Values followed by same letter are not significant at $\mathrm{p}>0.05$

Table 5: Total sugars, protein, crude fat, crude fibre and calorie value of $S$. brachiata under seawater irrigation

\begin{tabular}{lccccc}
\hline Treatments & Total sugar $\left(\mathrm{mg} \mathrm{g}^{-1}\right)$ & Protein $\left(\mathrm{mg} \mathrm{g}^{-1}\right)$ & Crude fat $(\%)$ & Crude Fibre (\%) & Calorie value $(100 \mathrm{~g})$ \\
\hline T0 & $26.2 \pm 0.23^{\mathrm{c}}$ & $18.1 \pm 0.13^{\mathrm{c}}$ & $0.33 \pm 0.07^{\mathrm{d}}$ & $13.2 \pm 0.19^{\mathrm{c}}$ & $209.7 \pm 2.13^{\mathrm{e}}$ \\
T1 & $27.4 \pm 0.16^{\mathrm{c}}$ & $19.7 \pm 0.09^{\mathrm{b}}$ & $0.39 \pm 0.09^{\mathrm{b}}$ & $14.6 \pm 0.24^{\mathrm{b}}$ & $221.3 \pm 2.35^{\mathrm{d}}$ \\
T2 & $31.3 \pm 0.12^{\mathrm{a}}$ & $23.2 \pm 0.11^{\mathrm{a}}$ & $0.46 \pm 0.07^{\mathrm{a}}$ & $15.8 \pm 0.31^{\mathrm{a}}$ & $261.7 \pm 2.08^{\mathrm{a}}$ \\
T3 & $28.1 \pm 0.21^{\mathrm{b}}$ & $22.8 \pm 0.07^{\mathrm{a}}$ & $0.41 \pm 0.08^{\mathrm{b}}$ & $14.9 \pm 0.33^{\mathrm{b}}$ & $247.8 \pm 1.74^{\mathrm{b}}$ \\
T4 & $26.8 \pm 0.32^{\mathrm{c}}$ & $18.2 \pm 0.06^{\mathrm{c}}$ & $0.36 \pm 0.11^{\mathrm{c}}$ & $13.9 \pm 0.24^{\mathrm{c}}$ & $210.3 \pm 2.12^{\mathrm{e}}$ \\
T5 & $29.3 \pm 0.38^{\mathrm{ab}}$ & $21.6 \pm 0.08^{\mathrm{ab}}$ & $0.40 \pm 0.09^{\mathrm{b}}$ & $14.7 \pm 0.21^{\mathrm{b}}$ & $231.7 \pm 1.48^{\mathrm{c}}$ \\
T6 & $27.8 \pm 0.14^{\mathrm{c}}$ & $20.6 \pm 0.11^{\mathrm{b}}$ & $0.38 \pm 0.13^{\mathrm{c}}$ & $14.2 \pm 0.43^{\mathrm{bc}}$ & $229.8 \pm 2.44^{\mathrm{c}}$ \\
\hline
\end{tabular}

Values are Mean $\pm S E ;$ Values followed by same letter are not significant at $p>0.05$

to $750 \mathrm{mM}$ ), the amount of protein in root and leaf tissues of Suaeda altissima drastically increases. Similarly, S. brachiata showed an increasing trend for total sugar content with the addition of $\mathrm{HC}$ up to 1 ton $\mathrm{ha}^{-1}\left(31.3 \mathrm{mg} \mathrm{g}^{-1}\right)$ and FYM up to 2 ton $\mathrm{ha}^{-1}\left(29.3 \mathrm{mg} \mathrm{g}^{-1}\right)$ compared to control (Table 5). This corroborates with an earlier report that under salinity, higher amount of total soluble sugars was observed in S. portulacastrum (Jothiramshekar et al., 2018). The sea water induced increase in sugar content with increasing age of control plants might be due to the starch-sugar inter-conversion to provide more sugar for osmoprotection (Slama et al., 2015). An increasing sugar content and corresponding decrease in the starch at higher salinities have been reported in several halophytes (Ashraf et al., 2010). As for the interaction effect of saline irrigation and biofertilizer inoculation, the highest values for the crude protein content was recorded in S. brachiata plants supplied with halophytic compost @ 1 ton ha ${ }^{-1}$ and irrigated with fullstrength seawater.

Proline content of the leafy shoots of $S$. brachiata was more in control plants than manure treated plants $\left(42.7 \mu \mathrm{mol} \mathrm{g} \mathrm{g}^{-1}\right)$. Greater accumulation of proline was observed in the halophytic plant without any soil amendments $\left(42.7 \mu \mathrm{mol} \mathrm{g} \mathrm{g}^{-1}\right)$ followed by the applications of HC@1 ton ha-1 $\left(36.1 \mu \mathrm{mol} \mathrm{g}{ }^{-1}\right)$ and FYM@ 9 ton ha $^{-1}\left(35.3 \mu \mathrm{mol} \mathrm{g}{ }^{-1}\right)$. There is no significant difference in plants amended with low dose of FYM whereas the increasing level of fertilizer application decreased the accumulation of proline (Table 4). There was a gradual rise in the level of proline on 60th day sampling in control plants when compared to the plants treated with fertilizers. The present observations are in accordance with several studies that proline content progressively increased with high levels of salinity in Sesuvium portulacastrum and Odyssea paucinervis (Naidoo et al., 2008). Similar to our results, increased level of proline in response to salt stress has been reported in many plants (Zakery-Asl et al., 2014). The total phenol content was varied in the different treatments and ranged from 1.34 to $1.93 \mathrm{mg}$
GAE g ${ }^{-1} \mathrm{DW}$ (Table 4). The maximum total phenol content was observed in control plants (T0) (1.93 $\left.\mathrm{mg} \mathrm{g}^{-1}\right)$ followed by $\mathrm{HC}$ treated plants where as the variation was insignificant among the FYM treatments. Ventura et al. (2011) mentioned that in Salicornia and Sarcocornia, total polyphenols are high (1.2 and

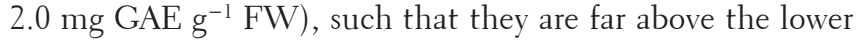
limit of other, non-halophytic leafy vegetables rated as rich in phenolic compounds (>0.5 mg GAE g ${ }^{-1} \mathrm{FW}$ ) (Isabelle et al., 2010). Many authors have reported salinity induced higher accumulation of polyphenols in many plants (Ksouri et al., 2008; Yuan et al., 2010) in order to counter the salinity induced oxidative damage. Similarly, the total ascorbic acid content was not significantly varied between control and $\mathrm{HC}$ treated plants where the maximum content of $6.23 \mathrm{mg} 100 \mathrm{~g} \mathrm{~g}^{-1}$ and $5.72 \mathrm{mg}$ $100 \mathrm{~g}-1$ was recorded in control and HC @ 1 ton ha ${ }^{-1}$ respectively. Lu et al. (2010) observed the total ascorbic acid content of 6 $\mathrm{mg} 100 \mathrm{~g}^{-1}$ fresh product in the highly saline-adapted shoots of $S$. bigelovii, values in the similar range of those for nonhalophyte leafy vegetables, such as spinach $\left(7 \mathrm{mg} 100 \mathrm{~g}^{-1}\right)$ and lettuce $\left(<2 \mathrm{mg} 100 \mathrm{~g}^{-1}\right)$.

\section{Mineral Nutrients and Food Value}

The present results clearly indicated that the application of different level of vermicompost and farmyard manure had considerable effects on the different mineral contents of Salicornia especially N, P, K, Ca, Cl and $\mathrm{Na}$ (Table 6). In the most cases, application of different manure levels resulted in significant increases in the values of $\mathrm{N}(30 \%), \mathrm{P}(13 \%), \mathrm{K}$ $(30 \%)$ and $\mathrm{Ca}(13 \%)$ but the amounts of sodium decreased compared to the control plants. Gradual increases in the above mentioned traits were noticed with the plants which received halophytic compost (1 ton ha-1) followed by FYM (2 ton ha-1). Suitable $\mathrm{K}^{+} / \mathrm{Na}^{+}$ratio has a key role for maintaining plant growth under saline condition. In the present study, addition of both $\mathrm{HC}$ and FYM significantly alleviated the salinity-induced $\mathrm{K}+$ deficiency and effectively increase the $\mathrm{K}^{+} / \mathrm{Na}^{+}$ratio in 
Table 6: Mineral nutrient status of $S$. brachiata cultivated under sea water irrigation

\begin{tabular}{lcccccccc}
\hline Treatments & $\mathrm{N}(\%)$ & $\mathrm{K}(\%)$ & $\mathrm{P}(\%)$ & $\mathrm{Na}\left(\mathrm{mg} \mathrm{g}^{-1}\right)$ & $\mathrm{Ca}\left(\mathrm{mg} \mathrm{g}^{-1}\right)$ & $\mathrm{Cl}\left(\mathrm{mg} \mathrm{g}^{-1}\right)$ & ${\mathrm{Mg}\left(\mathrm{mg} \mathrm{g}^{-1}\right)}^{\mathrm{Fe}\left(\mathrm{mg} \mathrm{g}^{-1}\right)}$ \\
\hline T0 & 1.29 & 5.2 & 5.8 & 0.363 & 0.332 & 0.732 & 0.106 & 0.106 \\
T1 & 1.36 & 5.9 & 6.2 & 0.342 & 0.352 & 0.582 & 0.153 & 0.083 \\
T2 & 1.66 & 6.7 & 6.6 & 0.338 & 0.381 & 0.551 & 0.172 & 0.118 \\
T3 & 1.53 & 6.2 & 6.5 & 0.326 & 0.367 & 0.517 & 0.138 & 0.093 \\
T4 & 1.31 & 5.3 & 5.9 & 0.332 & 0.343 & 0.563 & 0.148 & 0.109 \\
T5 & 1.46 & 6.1 & 6.3 & 0.329 & 0.361 & 0.541 & 0.129 \\
T6 & 1.43 & 5.4 & 6.1 & 0.321 & 0.337 & 0.513 & 0.089 \\
\hline
\end{tabular}

both shoot and root (Grewal, 2010). In addition to this, some earlier reports suggested that halophyte species may substitute $\mathrm{K}^{+}$for $\mathrm{Na}^{+}$to increase turgor pressure rapidly in epidermal cells (Shabala \& Mackay, 2011) which can be justified by the higher concentration of $\mathrm{K}+$ in S. brachiata treated with organic manure. Calcium and magnesium concentrations were extremely low in shoots of control plants compared to fertilizer treated plants agreeing with the results reported earlier for Salicornia and other halophytes (Mala et al., 2010). This was supported by Ventura et al. (2011) who observed enhanced values for these nutritive ions in Salicornia and Sarcocornia, whose final contents in edible portions was comparable to those in non-halophyte vegetables grown at moderate salinity. The calorie value of $S$. brachiata was calculated based on the determination of the basic proximate analysis of primary metabolites.

As per the recommendations of USDA the calorie value of the edible halophyte $S$. brachiata was calculated by multiplying the values of carbohydrate (4 times), protein (4 times), crude fibre (2 times) and crude fat (9 times). In our study, we observed that the mean serving of $100 \mathrm{~g}$ of S. brachiata leafy shoots contains a total calorie value of 262, 247 and 209 cultivated under HC@1 ton ha ${ }^{-1}$,FYM @2 ton ha ${ }^{-1}$ and control treatments, respectively. Since the proline content and toxic ionic concentrations were reduced in organic manure treated plants, they exhibited more consumable nature and increased caloric value. We observed in our study, that the amount of crude protein in S. brachiata cultivated in HC treated soil could sufficiently meet the minimum protein requirement of adult sheep or cattle i.e., 14 to $18 \%$ for growing or lactating animals (Ismail, 2015).

\section{CONCLUSIONS}

The present short term field experiment conducted at coastal inlands of Palk Bay region revealed that higher biomass productivity of $S$. brachiata can be achieved under sea water irrigation with the addition of nutrient $(\mathrm{N})$ supplements. This halophytic plant exhibited good adaption to salinity in terms of better plant growth, biomass and defense mechanisms through the accumulation of inorganic ions and development of succulence. The soil studies explained that the soil texture and the inherent soil nutrient levels play a significant role in plant performance in saline situations. Hence, Salicornia cultivated with highly saline water, are ideal leafy vegetables containing nutritional metabolites rich in antioxidant compounds that are indispensable to the human diet.

\section{REFERENCES}

Abbasi, G. H., Akhtar, J., Anwar-Ul-Haq, M., Ali, S., Chen, Z. H., \& Malik, W. (2014). Exogenous potassium differentially mitigates salt stress in tolerant and sensitive maize hybrids. Pakistan Journal of Botany, 46, 135-146.

Abdal, M. S. (2009). Salicornia Production in Kuwait. World Applied Sciences Journal, 6(8), 1033-1038.

Abusuwar, A. O., \& Al-Solimani, S. J. (2013). Effect of chemical fertilizers on yield and nutritive value of inter cropped Sorghum bicolor and Lablab purpureus forages grown under saline conditions. Journal of Animal and Plant Sciences, 23, 271-276.

AOAC. (1990). Official methods of the analytical chemist (15th Eds. Vol. 2.). Arlington, Virginia, USA: Association of Official Analytical Chemists.

Arnon D. I. (1949). Copper enzymes in isolated chloroplasts. Polyphenoloxidase in beta vulgaris. Plant Physiology, 24(1), 1-15. https://doi.org/10.1104/pp.24.1.1

Arya, R. (2017). Effect of fertilizer application on plant growth and fruit yield of salvadora persica plantation on salt affected soil in Arid Rajasthan. International Journal of Ecology and Environmental Sciences, 43, 4.

Ashraf, M., Ashraf, K., Mahmood, J., Akhter, F., Arshad, M, H. (2010). Phytoremediation of saline soils for sustainable agricultural productivity. In M. Ashraf, M. Ozturk, \& M. S. A. Ahmad (Eds.), Plant Adaptation and Phytoremediation (pp. 335-355). Berlin, Germany: Springer.

Bai, Y., Yiyun, Y., Wengang, Z., Chuanhui, G., Weijie, X., Lijuan, M., Yuhua, S., \& Feng K. (2017). Coastal mudflat saline soil amendment by dairy manure and green manuring. International Journal of Agronomy, 2017, 4635964. https://doi.org/10.1155/2017/4635964

Balakrishnan, V., Arul, M., Bagyalakshmi, B., Karuppuchamy, K., \& Ravindran, K. C. (2010). Mangrove compost used as an organic manure for evaluation of yield characteristics in Vigna mungo. Electronic Journal of Environmental, Agricultural and Food Chemistry, 9 (5), 829-837

Bates, L.S., Waldren, R.P., \& Teare, I.D. (1973). Rapid determination of free proline for water-stress studies. Plant Soil 39, 205-207 (1973). https:// doi.org/10.1007/BF00018060

Buhmann, A. K., Waller, U., Wecker, B., \& Papenbrock, J. (2015). Optimization of culturing conditions and selection of species for the use of halophytes as biofilter for nutrient-rich saline water. Agricultural Water Management, 149, 102-114. https://doi.org/10.1016/j. agwat.2014.11.001

Cassaniti, C., Romano, D., Hop, M. E. C. M., \& Flowers, T. J. (2013). Growing floricultural crops with brackish water. Environmental and Experimental Botany, 92, 165-175. https://doi.org/10.1016/j. envexpbot.2012.08.006

Durust, N., Sumengen, D., \& Durust, Y. (1997). Ascorbic acid and element contents of foods of Trabzon (Turkey). Journal of Agricultural and Food Chemistry, 45, 2085-2087. https://doi.org/10.1021/jf9606159

El-Quesni, F. E. M., Hashish, K. I., Kandil, M. M. \& Mazher, A. A. M. (2013). Impact of some biofertilizers and compost on growth and chemical composition of Jatropha curcas. World Applied Sciences Journal, 21(6), 927-932. https://doi.org/10.5829/idosi.wasj.2013.21.6.2907

Flowers, T. J., Galal, H. K., \& Bromham, L. (2010). Evolution of halophytes: multiple origins of salt tolerance in land plants. Functional Plant Biology, 37, 604-612. https://doi.org/10.1071/FP09269

Giudice, T. D., \& Pascucci, S. (2010). The role of consumer acceptance in the food innovation process: young consumer perception of functional foods in Italy. International Journal on Food System Dynamics, 2, 111-122. https://doi.org/10.18461/ijfsd.v1i2.123

Grewal, H. S. (2010). Water uptake, water use efficiency, plant growth 
and ionic balance of wheat, barley, canola and chickpea plants on a sodic vertosol with variable subsoil $\mathrm{NaCl}$ salinity. Agricultural Water Management, 97, 148-156. https://doi.org/10.1016/j. agwat.2009.09.002

Hamdia, M. A. E. S., Shaddad, M., \& Doaa, M. (2004). Mechanisms of salt tolerance and interactive effects of Azospirillum brasilense inoculation on maize cultivars grown under salt stress conditions. Plant Growth Regulation 44, 165-174. https://doi.org/10.1023/ B:GROW.0000049414.03099.9b

Hussein, M. M., Thalooth, A. T., Tawfik, M. M., Gobarah, M. E., \& Mohamed, M. H. (2012). Impact of mineral and organic fertilizer on vegetative growth of Jatropha curcas L. in sandy soil. Applied Botany, 49, 9714-9717.

Isabelle, M., Lee, B. L., Lim, M. T., Koh, W. P., Huang, D., \& Ong, C. N. (2010). Antioxidant activity and profiles of common vegetables in Singapore. Food Chemistry, 120, 993-1003. https://doi.org/10.1016/j. foodchem.2009.11.038

Islam, M. R., Haque, K. M. S., Akter, N., (2014). Karim, M. A. Leaf chlorophyll dynamics in wheat based on SPAD meter reading and its relationship with grain yield. Scientia Agriculturae, 8(1), 13-18. https://doi. org/10.15192/PSCP.SA.2014.4.1.1318

Ismail, A. S (2015). Nutritional and Feed Value of Halophytes and Salt Tolerant Plants. In H. M. El Shaer, \& V. R. Squires (Eds.). Halophytic and Salt-Tolerant Feedstuffs, Impacts on Nutrition, Physiology and Reproduction of Livestock. United States: CRC Press. https://doi. org/10.1201/b19862-10

Jackson, M. L. (1967). Soil chemical analysis (1 ${ }^{\text {st }}$ Eds.). London: Constable and $\mathrm{Co}$.

James, H. (1995). Analytical chemistry of foods (pp. 86). NewYork: Chapmen and Hall Press.

Joshi, A. J., Kumar, A. S., \& Heriglajia, H. (2002). Effect of seawater on germination, growth, accumulation of organic components and inorganic ions in halophytic grass Heleochola setulosa (TRIN). Blattet Mc Cann. Indian Journal of Plant Physiology, 7, 26-30.

Jothiramshekar, S., Benjamin, J. J., Krishnasamy, R., Pal, A. K., George, S., Swaminathan, R., \& Parida, A. K. (2018). Responses of selected C3 and $\mathrm{C} 4$ halophytes to elevated $\mathrm{CO} 2$ concentration under salinity. Current Science, 115(1), 129-135. https://doi.org/10.18520/cs/v115/ i1/129-135

Kalaiarasi, T., \& Arumugam, R. (2014). Impact of halophytic compost and compost tea on plant growth, biochemical composition, yield and pathogenic resistance of tomato (Lycopersicon esculentum $\mathrm{L}$. cultivar. CO-1) under field conditions. Journal of Modern Science, 6(1), 1 - 16.

Khan, M. A., Ansari, R., Ali, H., Gul, B., \& Nielsen, B. L. (2009). Panicum turgidum, a potentially sustainable cattle feed alternative to maize for saline areas. Agriculture, Ecosystems \& Environment, 129(4), 542-546. https://doi.org/10.1016/j.agee.2008.10.014.

Kirk, B., \& Sawyer, A. (1980). Pearsons Food composition and analysis (pp. 34). England: Longman Press.

Ksouri, R., Megdiche, W., Falleh, H., Trabelsi, N., Boulaaba, M., Smaoui, A., \& Abdelly, C. (2008). Influence of biological, environmental and technical factors on phenolic content and antioxidant activities of Tunisian halophytes. Comptes rendus biologies, 331(11), 865-873. https://doi.org/10.1016/j.crvi.2008.07.024

Kudo, N., \& Fujiyama, H. (2010). Responses of Halophyte Salicornia bigelovii to different forms of nitrogen source. Pedosphere, 20, 311-317. https://doi.org/10.1016/S1002-0160(10)60019-7

Kumar, P., Pannu, R. K., \& Khokhar, S. K. (2012). Effect of organic sources of nutrition and irrigation levels on growth and yield of wheat ( $T$. aestivum). International Journal of Life Science and Pharma Research, 1(4), 177-186.

Lin, J. Y., \& Tang, C. Y. (2007). Determination of total phenolic and flavonoid contents in selected fruits and vegetables, as well as their stimulatory effects on mouse splenocyte proliferation. Food Chemistry, 101, 140147. https://doi.org/10.1016/j.foodchem.2006.01.014

Liu, X. Z., Wang, C. Z., Su, Q., \& Li, C. K. (2012). The potential resource of halophytes for developing bio-energy in China coastal zone. Herald Journal of Agriculture and Food Science Research, 1, 44-51.

Lordan, J., Pascual, M., \& Fonseca, F. (2013). Use of rice husk to enhance peach tree performance in soil switch limiting physical properties. Soil and Tillage Research 129, 19-22. https://doi.org/10.1016/j. still.2013.01.002

Lowry, O. H., Rosenbrough, N. J., Far, A. L., \& Randall, R. J. (1951). Protein measurement with the folin-phenol reagent. Journal of Biological
Chemistry, 193, 265-275.

Lu, D., Zhang, M., Wang, S., Cai, J., Zhou, X., \& Zhu, C. (2010). Nutritional characterization and changes in quality of Salicornia bigelovii Torr. during storage. LWT - Food Science and Technology, 43, 519-524. https://doi.org/10.1016/j.lwt.2009.09.021

Mala, P., Umamaheswari, M., Jayakumari, M., Maheswari, K., Subashree, M. Sevanthi, T., \&Manikandan, T. (2010). Growth and salt balance of the halophyte Salicornia brachiata in relation to salinity. Asian Journal of Science and Technology, 1, 12-15.

Martinez-Garcia, R. (2010). Physiological studies of the halophyte Salicornia bigelovii: A potential food and biofuel crop for integrated aquaculture - agricultural systems. Doctoral Dissertation, University of Arizona, Tucson, Arizona.

Meychik, N. R., Nikolaeva, Y. I., \& Yermakov, I. P. (2013). Physiological Response of Halophyte (Suaeda altissima (L.) Pall.) and Glycophyte (Spinacia oleracea L.) to Salinity. American Journal of Plant Sciences, 4, 427-435. https://doi.org/10.4236/ajps.2013.42A055

Naidoo, G., Somaru, R., \& Achar, P. (2008). Morphological and physiological responses of the halophyte, Odyssea paucinervis (Staph) (Poaceae), to salinity. Flora - Morphology Distribution Functional Ecology of Plants 203(5), 437-447. https://doi.org/10.1016/j.flora.2007.08.003

Nile, S. H. \& Khobragade, C. N. (2009). Determination of nutritive value and mineral elements of some important medicinal plants from Western Part of India, Journal of Medicinal Plants, 8(5), 79 - 88.

Noaman, M. N. (2004). Effect of potassium and nitrogen fertilizers on the growth and biomass of some halophytes grown under high levels of salinity. Journal of Agronomy, 3, 25-30.

Panta, S., Flowers, T., Lane, P., Doyle, R., Haros, G., \& Shabala, S. (2014). Halophyte agriculture: Success stories. Environmental and Experimental Botany, 107, 71-83. https://doi.org/10.1016/j. envexpbot.2014.05.006

Parida, A. K., Veerabathini, S. K., Kumari, A., \& Agarwal, P. K. (2016). Physiological, Anatomical and metabolic implications of salt tolerance in the halophyte Salvadora persica under Hydroponic Culture Condition. Frontiers in Plant Science, 7, 351. doi: https://doi. org/10.3389/fpls.2016.00351

Premchandra, G. S., Saneoka, H., \& Ogata, S. (1990). Cell membrane stability, an indicator of drought tolerance as affected by applied nitrogen in soybean. Journal of Agricultural Science, 115, 63-66.

Radulovic, R., Rodríguez, M. J., \& Rebeca, M. (2017). Growing halophytes floating at sea. Aquaculture Reports, 8, 1-7.

Rothballer, M., Schmid, M., Fekete, A., \& Hartmann, A. (2005), Comparative in situ analysis of ipdC-gfpmut3 promoter fusions of Azospirillum brasilense strains Sp7 and Sp245. Environmental Microbiology, 7, 1839-1846. https://doi.org/10.1111/j.1462-2920.2005.00848.x

Rueda-Puente, E. O., Castellanos, T., Troyo-Dieguez, E., \& Diaz de LeonAlvarez, J. L. (2004). Effect of Klebsiella pnuemoniae and Azospirillum halopraeferens on the growth and development of two Salicornia bigelovii genotypes. Australian Journal of Experimental Agriculture, 44, 65 - 74. https://doi.org/10.1071/EA03012

Shabala, S., \& Mackay, A., (2011). Ion Transport in Halophytes. In I. Turkan (Eds.), Advances in Botanical Research (pp. 151-199). Cambridge: Academic Press. https://doi.org/10.1016/B978-0-12-387692-8.00005-9.

Sheikhi, J., \& Ronaghi, A. (2013). Effect of salinity and vermicompost application on nutrients concentration and yield of spinach cv. Virofly in a calcareous soil. Journal of Science and Technology of Greenhouse Culture, 4(13), 93

Singh, A., Sharma, S., \& Shah, M. T. (2018). Successful Cultivation of Salicornia brachiata - A Sea Asparagus Utilizing RO Reject Water: A Sustainable Solution. International Journal of Waste Resources, 8 322. https://doi.org/10.4172/2252-5211.1000322

Slama, I., Abdelly, C., Bouchereau, A., Flowers, T., \& Savouré, A. (2015) Diversity, distribution and roles of osmoprotective compounds accumulated in halophytes under abiotic stress. Annals of Botany, 115(3), 433-447. https://doi.org/10.1093/aob/mcu239

Slama, I., Ghnaya, T., Messedi, D., Hessini, K., Labid, N., Svoure, A., \& Abdelly, C. (2008). Effects of sodium chloride on the response of the halophyte species Sesuvium portulacastrum grown in mannitolinduced water stress. Journal of Plant Research, 120, 291-299. https:// doi.org/10.1007/s10265-006-0056-x

Stanford, S., \& English, L. (1949). Use of flame photometer for analysis of $\mathrm{Na}, \mathrm{K}$ and Ca. Agronomy Journal, 41, 446-447.

Tavakkoli, E., Fatehi, F., Coventry, S., Rengasamy, P., McDonald, G. K. (2011) Additive effects of $\mathrm{Na}+$ and $\mathrm{Cl}$-ions on barley growth under salinity 
stress. Journal of Experimental Botany, 62(6), 2189-2203. https://doi. org/10.1093/jxb/erq422

Tawfik, M. M., Badr, E. A, \& Talooth, A. T. (2019). Smart farming practices to promote growth and productivity of Atriplex (nummularia) in saline habitats. International Journal of Agriculture, Forestry and Life Sciences, 3(1), 161-170.

Tejada, M., Hernandez, M. T., \& Garcia, C. (2006). Application of two organic amendments on soil restoration: effects on the soil biological properties. Journal of Environmental Quality, 35(4), 1010-1017. https://doi.org/10.2134/jeq2005.0460

Ventura, Y., \& Sagi, M. (2013). Halophyte crop cultivation: The case for Salicornia and Sarcocornia. Environmental and Experimental Botany, 92, 144-153. https://doi.org/10.1016/j.envexpbot.2012.07.010

Ventura, Y., Eshel, A., Pasternak, D., \& Sagi, M. (2015). The development of halophyte-based agriculture: past and present. Annals of Botany, 115(3), 529-540. https://doi.org/10.1093/aob/mcu173

Ventura, Y., Myrzabayeva, M., Alikulov, Z., Cohen, S., Shemer, Z., \& Sagi, M. (2013). The importance of iron supply during repetitive harvesting of Aster tripolium. Functional Plant Biology 40, 968-976. https://doi. org/10.1071/FP12352

Ventura, Y., Wuddineh, W. A., Myrzabayeva, M., Alikulov, Z., KhozinGoldberg, I., Shpigel, M., Samocha, T. M., \& Sagi, M. (2011). Effect of seawater concentration on the productivity and nutritional value of annual Salicornia and perennial Sarcocornia halophytes as leafy vegetable crops. Scientia Horticultura, 128, 189-196. https://doi. org/10.1016/j.scienta.2011.02.001

Webb, J. M., Quintã, R., Papadimitriou, S., Norman, L., Rigby, M., Thomas, D. N., \& Le Vay, L. (2012). Halophyte filter beds for treatment of saline wastewater from aquaculture. Water Research, 46(16), 5102-5114. https://doi.org/10.1016/j.watres.2012.06.034

Yuan, G., Wang, X., Guo, R., \& Wang, Q. (2010). Effect of salt stress on phenolic compounds, glucosinolates, myrosinase and antioxidant activity in radish sprouts. Food Chemistry, 121, 1014-1019. https:// doi.org/10.1016/j.foodchem.2010.01.040

Zakery-Asl, M. A., Bolandnazar, S., \& Oustan, S. (2014) Effect of salinity and nitrogen on growth, sodium, potassium accumulation, and osmotic adjustment of halophyte Suaeda aegyptiaca (Hasselq.) Zoh. Archives of Agronomy and Soil Science, 60(6), 785-792. https://doi.org/10.10 80/03650340.2013.841889

Zemanová, V., Kateřina, B., Daniela, P., Pavla, K., \& Pavel, T. (2017). Effect of biochar application on the content of nutrients ( $\mathrm{Ca}, \mathrm{Fe}, \mathrm{K}, \mathrm{Mg}$, $\mathrm{Na}, \mathrm{P}$ ) and amino acids in subsequently growing spinach and mustard. Plant, Soil and Environment, 63(7), 322- https://doi. org/327.10.17221/318/2017-PSE 